УДК 621.43 .05

DOI https://doi.org/10.32838/2663-5941/2021.5/43

Урум Н.С.

Дунайський інститут водного транспорту Державного університету інфраструктури та технологій

Рященко О.I.

Дунайський інститут водного транспорту Державного університету інфраструктури та технологій

\title{
Ліганенко В.В.
}

Дунайський інститут водного транспорту Державного університету інфраструктури та технологій

Бабере О.С.

Дунайський інститут водного транспорту Державного університету інфраструктури та технологій

\section{МЕТОД ІНТЕНСИФІКАЦІЇ ПРОЦЕСУ ЗГОРЯННЯ ПАЛИВА У СУДНОВОМУ ДИЗЕЛІ}

Енергетика є однією з основ існування та розвитку земної цчивілізації. За рік на планеті спалюється більш 4,5 млрд т. вугілля і більш 3,5 млрд т. нафти. В економічній політиці всіх розвинутих країн пріоритетним напрямком є інтенсифікація наукових досліджень у галузі енергозбереження. Завдяки своїи енергетичній ефективності дизелі на даний час витиснули іниі типи енергетичних установок на суднах річкового і морського флоту, а у доступному для огляду майбутньому вони збережуть домінуюче положення. Прачююючий дизель є інтенсивним джерелом шумового, теплового та хімічного забруднення навколишнього середовища. Проблема скорочення викидів забруднюючих речовин прачюючим дизелем є одним із найважливіших завдань дизелебудування, від рішення якого залежсть стан здоров'я людини і збереження навколишнього середовища. Покрашення екологічних та енергетичних характеристик дизеля можливо за рахунок інтенсифікації згоряння палива, методам забезпечення якого і присвячена дана стаття.

У статті розкрито сутності методу інтенсифікації процесу згоряння палива у судновому дизелі.

Відомо, шуо швидкість поширення паливного струменя в дизелі перевишує 120 м/с. Вершина паливного струменя практично миттєво досягне стінки камери згоряння, $і$ краплі палива неминуче ввійдуть у зіткнення з поверхнею камери згоряння, як иче здійснюється в камері згоряння МАН.

Відповідно до загальноприйнятих представлень відмінною рисою камери згоряння МАН є використання в ній переважно плівкового сумішоутворення, щуо одержало назву «М-процес».

Відмінною рисою камери згоряння дизеля «ЕЛКО» від камери згоряння МАН є нахил частини верхньої горизонтальної площчин поршня всередину камери згоряння під кутом 9 градусів. Таке додаткове профілювання верхньої частини пориня буде сприяти посиленню амплітуди пульсацій радіальної стоячої хвилі вище зазначеного граничного значення. У момент спалаху палива, при перебуванні поршня у верхній мертвій точці, у місці переходу похилої поверхні пориня в горизонтальну (у місці пучності радіальної стоячої хвилі) швидкість перетікання газу збільшиться. Тобто збільшиться амплітуда пульсацій, щзо може перевищити граничне значення.

Отюе, в камері згоряння дизеля «ЕЛКО» створені умови для збереження і додаткового збільшення амплітуди газодинамічних коливань у формі радіальної стоячої хвилі з довжиною на півхвилі, щзо дорівнює 1/3 діаметра цииліндра.

Ключові слова: інтенсифікація, прочес згоряння, судновий дизель, теорія двигуна, енергетика.

Постановка проблеми. Енергетика є однією 3 основ існування та розвитку земної цивілізації. За рік на планеті спалюється більш 4,5 млрд т. вугілля i більш 3,5 млрд т. нафти. За такою витратою енергії неминуче варто очікувати настання енергетичної кризи. В економічній політиці всіх розвинутих країн пріоритетним напрямком є інтенсифікація наукових досліджень у галузі енергозбереження. Завдяки своїй енергетичній ефективності дизелі на даний час витиснули інші типи енергетичних установок на суднах річкового і морського флоту, а у доступному для огляду майбутньому вони збережуть домінуюче положення. Працюючий дизель $\epsilon$ інтенсивним джерелом шумового, теплового та хімічного забруднення навколишнього середовища. Проблема скорочення викидів забруднюючих речовин працюючим дизелем є одним i3 найважливіших завдань дизелебудування, 
від рішення якого залежить стан здоров' я людини i збереження навколишнього середовища. Покращення екологічних та енергетичних характеристик дизеля можливо за рахунок інтенсифікації згоряння палива, методам забезпечення якого i присвячена дана стаття.

Аналіз останніх досліджень і публікацій. Літературні джерела, які використані під час написання статті, можна розділити на ряд взаємопов'язаних груп:

- теорії машин та конструювання;

- теорії суднобудівництва;

- теорії двигуна;

- фізичної хімії.

Постановка завдання. Метою статті $є$ розкриття сутності методу інтенсифікації процесу згоряння палива в судновому дизелі.

Виклад основного матеріалу дослідження. Відомо, що швидкість поширення паливного струменя в дизелі перевищує 120 м/с. Вершина паливного струменя практично миттєво досягне стінки камери згоряння, і краплі палива неминуче ввійдуть у зіткнення 3 поверхнею камери згоряння, як це здійснюється в камері згоряння МАН.

Відповідно до загальноприйнятих представлень, відмінною рисою камери згоряння МАН є використання в ній переважно плівкового сумішоутворення, що одержало назву «М-процес» [1; 2].

На рисунку 1 схематично позначена камера згоряння МАН.

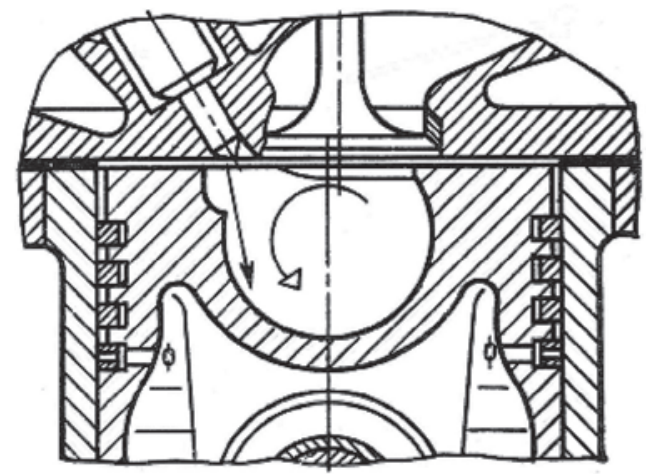

Рис. 1. Схематичне позначення камери згоряння дизеля

При плівковому сумішоутворенні 90-95\% палива розтікається по внутрішній стінці поршня, а 5-10\%, розпилюється в об'ємі камери згоряння. Для цього температура стінки поршня повинна підтримуватися в інтервалі $600-700^{\circ} \mathrm{C}$. Така температура є достатньою для інтенсивного випару плівки палива, але недостатньою для термічного розкладання (крекінгу) дизельного палива.
Паливо в камеру згоряння дизеля впорскувалося за допомогою форсунки, яка має один розпилюючий отвір, вісь якого розташовувалася під кутом близько 15 градусів до стінки циліндра. Спочатку використовувалася форсунка 3 двома розпилюючими отворами різного діаметра, але згодом було залишено тільки один.

Необхідною умовою плівкового сумішоутворення в камері згоряння дизеля $є$ осьове закручення повітряного заряду 3 метою відводу від стінки поршня парів палива. Здійснити досить ефективний круговий рух повітря в камері згоряння представляється можливим тільки у високооборотних двигунах [3].

Напрямок руху паливного струменя в камері згоряння дизеля збігається 3 напрямком інтенсивного обертального руху повітряного заряду.

У камері згоряння дизеля при русі поршня до верхньої мертвої точки (ВМТ) спочатку спалахують пари палива, які розпилені в об'ємі камери згоряння (5-10\% від кількості циклової подачі), а потім відбувається запалення та згоряння парів палива, що поступово випаровуються зі стінки поршня. Випаровування паливної плівки здійснюється в основному за рахунок теплоти, яка передана від полум'я та продуктів згоряння.

Завдяки такій конструкції в дизелях 3 «М-процесом» згоряння палива відбувається дуже м'яко, досить повно та бездимно. Коефіцієнт надлишку повітря складає 1,15-1,2, а мінімальна питома ефективна витрата палива 165 г/(е.л.с.год.) [5].

Основними перевагами процесу плівкового сумішоутворення $€$ [5]:

- низька питома витрата палива порівняно 3 витратою палива в дизелях з об'ємним сумішоутворенням;

- мала швидкість наростання тиску за кутом повороту колінчатого вала $(d \rho / d \varphi)$ та низькі значення максимального тиску згоряння $\left(P_{z}\right)$;

- можливість організації якісного робочого процесу в малорозмірних високооборотних дизелях;

- багатопаливність (здатність працювати 3 різними видами палива);

- невисокі вимоги до якості виготовлення паливної апаратури (використовується форсунка 3 одним розпилюючим отвором).

До недоліків плівкового сумішоутворення відносяться:

- неможливість застосування цього способу в двигунах великої розмірності та з малою частотою обертання колінчатого вала у зв'язку з труднощами організації інтенсивного вихрового руху повітряного заряду;

- низькі пускові якості, а також погіршення економічних та екологічних показників дизеля під час роботи на часткових режимах у зв'язку зі зниженням температури стінки камери згоряння менше необхідного оптимального значення [5]. 
Експериментальні дослідження підтверджують можливість існування паливної плівки в умовах, що відповідають умовам у камері згоряння дизеля.

М.M. Кухарєв [6] вважає, що рідка плівка на стінках камери згоряння може існувати тільки в режимі пуску і прогріву дизеля. На основі проведених експериментальних досліджень він дійшов висновку, що влучення рідкого палива на стінку камери згоряння небажане. При досить високій температурі поверхні (вище $823^{\circ} \mathrm{C}$ ) рідке паливо утворює парову подушку i не змочує стінку камери згоряння.

Результати експериментальних досліджень, що були виконані В.В. Загоровським, свідчать, що в області низьких температур (до $613^{\circ} \mathrm{C}$ ) краплі дизельного палива, які падають на нагріту поверхню, утворюють стійку плівку. Швидкість випару паливної плівки різко зростає зі збільшенням температури стінки [7].

У діапазоні температур від 613 до $637^{\circ} \mathrm{C}$ плівка стає хиткою. Відбуваються розриви плівки та утворення рухливих кульок палива, які випаровуються. Швидкість випару крапель палива, які утворилися, значно знижується.

Експериментальні дослідження підтвердили, що при температурі вище $700^{\circ} \mathrm{C}$ плівка не утвориться, і крапля палива може розбитися на декілька крапель. Між краплями та розпеченою поверхнею утворюється парова подушка, і краплі починають інтенсивно переміщуватися по гарячій пластині. У цьому випадку швидкість випару краплі зі збільшенням температури стінки знижується, час випару розпиленого палива різко збільшується.

Аналогічну картину можна спостерігати й у побуті, під час влученні крапель води на розпечену поверхню плити.

На рисунку 2 наведені результати дослідження випару краплі дизельного палива, яка потрапляє

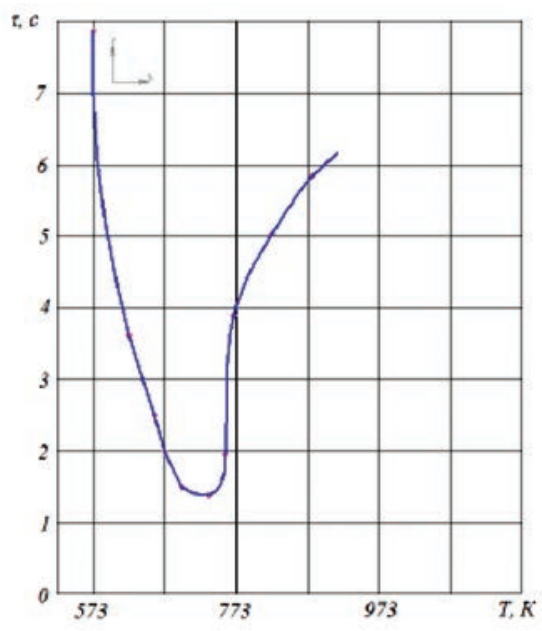

Рис. 2. Залежність часу випаровування краплі дизельного палива від температури на нагріту металеву поверхню, що отримані В.В. Загоровським [7].

Якщо отримані В.В. Загоровським результати експериментальних досліджень перенести на камеру згоряння дизеля, то 3 великою долею ймовірності можна допустити, що в розробленій конструкції «теплоізольованого» (за визначенням Л. Ельсбетта) двигуна час згоряння грубо розпиленого палива під час влучення на розпечену стінку камери згоряння повинен значно збільшитися.

У цьому випадку процес згоряння повинен зміститися на лінію розширення, що призведе до збільшення питомої витрати палива, температури відпрацьованих газів (ВГ) та вмісту шкідливих речовин них.

Необхідно відзначити, що напрямок руху паливного струменя в камері згоряння дизеля збігається з напрямком руху повітряного заряду, закрученого щодо центральної осі камери згоряння. Тому ефекту покращення сумішоутворення i згоряння за рахунок обдуву краплі розпиленого палива також очікувати не слід.

Проведений аналіз дає підставу зробити висновок, що в конструкції дизеля реалізований невідомий раніше новий принцип інтенсифікації робочого процесу.

Умовами існування поперечних радіальних стоячих хвиль $є$ кратне співвідношення діаметра камери згоряння та діаметра циліндра, а також циліндричної камери згоряння в поршні, яка розташована на одній осі з віссю циліндра [8].

У дизелів типу Ч 9,5/11 і Ч 14/14 з вісесиметричною циліндричною камерою згоряння в поршні відношення діаметра циліндричний камери згоряння в поршні до діаметра циліндра дорівнює 0,5. Цей тип камер згоряння у порівнянні $з$ іншими напіврозділеними камерами згоряння має кращі показники за питомою ефективністю витрати палива.

У цих камерах згоряння створені умови для збереження енергії поперечних радіальних стоячих хвиль, що збуджуються в процесі наповнення циліндра свіжим повітряним зарядом. Отримані пульсації газового середовища впливають на процеси струминного сумішоутворення, сприяючи вирівнюванню концентрації палива в обсязі струменя, а також інтенсифікації процесів тепломасообміну між краплями розпиленого палива й нагрітим газовим середовищем.

На рисунку 3 наведені епюри тиску та швидкості пульсацій газу в радіальній стоячій хвилі в камері згоряння зі співвідношенням діаметра циліндра до діаметра камери згоряння, що дорівнює 0,5 .

Із рисунку 3 видно, що в камері згоряння в поршні укладається одна хвиля (дві напівхвилі), а в циліндрі - дві хвилі (чотири напівхвилі). 
Розглянемо камеру згоряння дизеля, діаметр камери згоряння в поршні якого дорівнює 1/3 діаметра циліндра. Отже, тут також виконується умова збереження радіальної стоячої хвилі 3 довжиною на півхвилі, що дорівнює діаметру камери згоряння в поршні і трьома напівхвилями в циліндрі. На рисунку 4 наведені епюри швидкості і тиску пульсацій радіальної стоячої хвилі в камері згоряння зі співвідношенням діаметра циліндра до діаметра камери згоряння, що дорівнює 1/3.

Позначення параметрів аналогічні позначенням, приведеним на рисунку 3.

Нижнім граничним значенням впливу обдуву краплі палива пульсаціями повітря на процес горіння є інтенсивність пульсацій понад 120 дб. Отже, у камери згоряння дизеля потужність пульсацій перевищила це граничне значення.

Відмінною рисою камери згоряння дизеля «ЕЛКО» від камери згоряння МАН $є$ нахил частини верхньої горизонтальної площини поршня всередину камери згоряння під кутом 9 градусів. Таке додаткове профілювання верхньої частини поршня буде сприяти посиленню амплітуди пульсацій радіальної стоячої хвилі вище зазначеного граничного значення. У момент спалаху палива, при перебуванні поршня у верхній мертвій точці (BMT), у місці переходу похилої поверхні поршня в горизонтальну (у місці пучності радіальної стоячої хвилі) швидкість перетікання газу збільшиться. Отже, і збільшиться амплітуда пульсацій, що може перевищити граничне значення.

На рисунку 5 представлені епюри швидкості і тиску в радіальній стоячій хвилі в камері згоряння
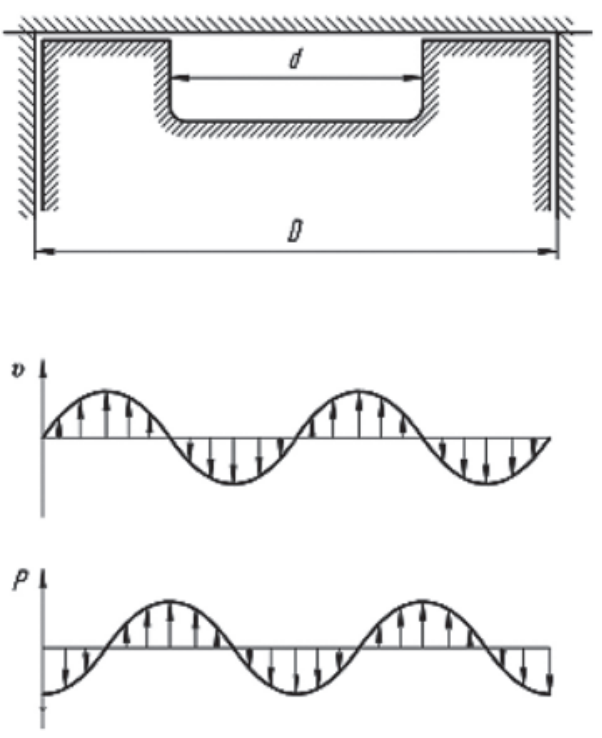

Рис. 3. Епюри швидкості та тиску пульсацій газового середовища у формі радіальної стоячої хвилі в циліндричній камері згоряння дизелів Ч 9,5/11 й Ч 14/14

$D$ - діаметр циліндру; $d$ - діаметр камери згоряння в поршні; v - швидкість пульсацій газу; $P$ - тиск газу

дизеля типу «ЕЛКО» із профільованою верхньою поверхнею поршня.

Позначення параметрів аналогічні позначенням, приведеним на рисунку 4. Затемнена частина епюр показує збільшення амплітуди пульсацій за рахунок підвищення швидкості газу в радіальній стоячій хвилі в районі пучності.
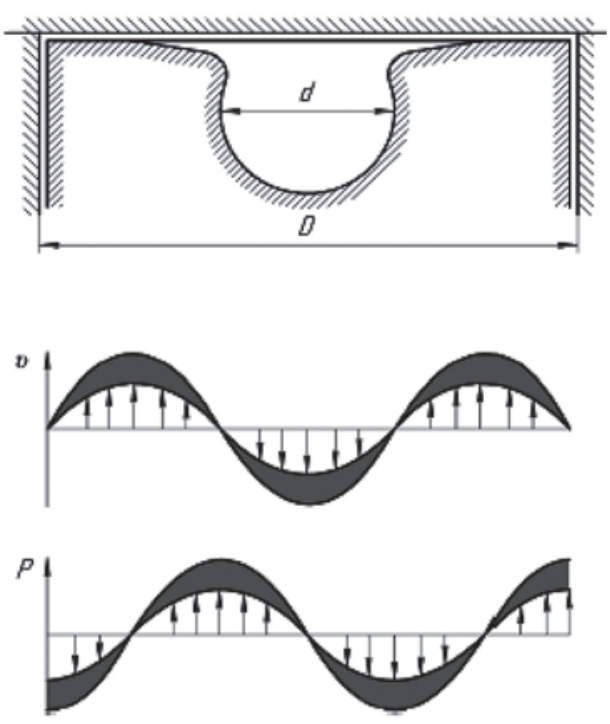

Рис. 5. Епюри тиску і швидкості радіальної стоячої хвилі в камері згоряння «ЕЛКО», що має профільовану верхню поверхню поршня 
Висновки. Таким чином, можна зробити висновок, що в камері згоряння дизеля «ЕЛКО» створені умови для збереження і додаткового збільшення амплітуди газодинамічних коливань у формі радіальної стоячої хвилі з довжиною на півхвилі, що дорівнює $1 / 3$ діаметра циліндра.

\section{Список літератури:}

1. Иващенко Н.А., Вагнер В.А., Грехов Л.В. Дизельные топливные системы с электронным управлением : учебно-практическое пособие. Барнаул : Алт. ГТУ им И.И. Ползунова, 2000. 111 с.

2. Грехов Л.В., Иващенко Н.А., Марков В.А. Топливная аппаратура и системы управления дизелей : учебник для вузов. 2-ге вид. Москва : Легион-Автодата, 2005. 344 с.

3. Писчаненко В.В. Исследование динамики вихреобразования в плоской цилиндрической камере с диаметрально направленной осесимметричной струей. Научные труды. 2006. № 2. С. 12-31.

4. Малов Р.В. Рабочие процессы и экологические качества ДВС. Автомобильная промышиленность. 1992. № 9. С. 10-15.

5. Лебедев О.Н., Сомов В.А., Калашников С.А. Двигатели внутреннего сгорания речных судов. Москва : Транспорт, 1990. 328 с.

6. Кухарев М.Н. О механизме пленочного смесеобразования. Труды ВСХИ. 1978. Т. 99. С. 60-66.

7. Загоровский В.В., Куделин О.Г., Лебедев О.Н. Экспериментальное исследование процесса испарения топливной пленки. Исследование и методы повышения технической эксплуатаиии СЭУ. 1984. C. $48-54$.

8. Юр Г.С. Волновые процессы в судовых дизельных энергетических установках. Новосибирск : НГАВТ, 1999. $109 \mathrm{c}$.

\section{Urum N.S., Ryashchenko O.I., Liganenko V.V., Babere O.S. METHOD OF INTENSIFICATION OF FUEL COMBUSTION PROCESS IN MARINE DIESELS}

Energy is one of the foundations of the existence and development of earthly civilization. More than 4.5 billion tons of coal and more than 3.5 billion tons of oil are burned on the planet every year. In the economic policy of all developed countries, the priority is to intensify research in the field of energy saving. Due to their energy efficiency, diesels have now supplanted other types of power plants on river and sea vessels, and in the foreseeable future they will maintain a dominant position. Running diesel is an intensive source of noise, heat and chemical pollution. The problem of reducing emissions of pollutants by running diesel is one of the most important tasks of diesel engineering, the solution of which depends on human health and the environment. Improving the environmental and energy performance of diesel is possible due to the intensification of fuel combustion, the methods of which this article is devoted to. The article reveals the essence of the method of intensification of the fuel combustion process in marine diesel. It is known that the speed of fuel jet propagation in a diesel engine exceeds $120 \mathrm{~m} / \mathrm{s}$. The top of the fuel jet will almost instantly reach the wall of the combustion chamber, and the fuel droplets will inevitably collide with the surface of the combustion chamber, as is done in the combustion chamber MAN. According to conventional beliefs, a distinctive feature of the combustion chamber of the Academy of Sciences is the use of mainly film mixture formation, which is called "M-process". A distinctive feature of the combustion chamber of the diesel engine "ELKO" from the combustion chamber $M A N$ is the inclination of the upper horizontal plane of the piston inside the combustion chamber at an angle of 9 degrees. This additional profiling of the upper part of the piston will increase the amplitude of the pulsations of the radial standing wave above the specified limit value. At the time of the fuel outbreak, when the piston is at the top dead center, at the transition of the inclined surface of the piston to the horizontal (at the point of incidence of the radial standing wave), the gas flow rate will increase. That is, the amplitude of the pulsations will increase, which may exceed the limit value. Therefore, in the combustion chamber of the diesel engine "ELKO" created conditions for maintaining and further increasing the amplitude of gas-dynamic oscillations in the form of a radial standing wave with a half-wavelength equal to $1 / 3$ of the diameter of the cylinder.

Key words: intensification, combustion process, marine diesel engine, engine theory, energy. 